\title{
MACRO-ELEMENTS AND TRACE ELEMENTS IN CEREAL GRAINS CULTIVATED IN LATVIA
}

\author{
Ida Jākobsone ${ }^{1}$, Ināra Kantāne ${ }^{1}$, Sanita Zute ${ }^{2}$, Inga Jansone ${ }^{2}$, \\ and Vadims Bartkevičs ${ }^{1}$ \\ ${ }^{1}$ Chemistry Department, University of Latvia, Kr. Valdemāra iela 48, Rīga, LV-1013, LATVIA; \\ ida.jakobsone@lu.lv \\ ${ }^{2}$ State Stende Cereal Breeding Institute, „Dižzemes”, Dižstende, Lībagi Civil Parish, Talsi County, LV-3258, LATVIA
}

Communicated by Māris Kḷaviṇš

\begin{abstract}
Cereal-based foods have great importance in the compensation of micro- and trace element deficiency, because $50 \%$ of the foods produced worldwide are made up of cereal grains. The aim of the research was to determine the concentration of macro-elements and trace elements in different cereals cultivated in Latvia. Various cereals were used in the research: rye $(n=45)$, barley $(n=54)$, spring wheat $(n=27)$, winter wheat $(n=53)$, triticale $(n=45)$ and oats $(n=42)$. Thirteen macro- and trace elements (Cd, Pb, Ni, Cr, Al, Cu, K, Na, Mn, Fe, Zn, Mg, Ca) were determined in cereal grain samples $(n=266)$. Macro-elements and trace elements varied significantly $(\mathrm{p}<$ 0.01 or $\mathrm{p}<0.001)$. The highest concentrations of macro- and trace elements were found in oats and the lowest in rye. The obtained data will expand the opportunity for food and nutrition scientists to evaluate content of the examined elements in grain products, and dietary consumption (bioavailability) of the examined macro-elements and trace elements.
\end{abstract}

Key words: cereals, rye, wheat, barley, oats, triticale, macro-elements, trace elements.

\section{INTRODUCTION}

World cereal production is high. In terms of quantity and area, wheat is by far the most popular cereal grown in the EU, making up nearly half the total. Of the remaining 50\%, about one-third is maize and one-third is barley. Other cereals grown in smaller quantities include triticale, rye, oats, and spelt. Nearly two-thirds of EU's cereal crop is used for animal feed, with around one-third for human consumption. Only 3\% is used for biofuels (Anonymous, 2015).

Cereal grains have been a primary source of nourishment for humans for thousands of years (Awika, 2011). Cereal group provide significant amounts of most nutrients and form an important part of a balanced diet in many countries (Dewettinck et al., 2008; Poutanen, 2012).

In daily consumption, cereal grains like barley, wheat, oats, rye, and triticale are used. Triticale (Triticosecale Whitm.) is a hybrid of wheat (Triticum sp.) and rye (Secale sp.). It contains high levels of nutritionally beneficial compounds (Rakha et al., 2011). Each crop plays an important role in different food industry areas: barley is commonly used for beer production, wheat and rye in bakery products, and oats for oatmeal and musli. Triticale is mainly used as an ingredient in animal feed, but also on a smaller scale is used as a food ingredient, for example in bread, cookies, cakes (Doxastakis et al., 2002; McKevith, 2004).
Cereals are the major staple food crop, contributing most of the human daily calorie intake in many cultures, as well as relevant quantities of minerals (Lombardi-Boccia, 2003).

Today, cereal grains are the single most important source of calories to a majority of the world population (Awika, 2011). However, other nutrients than protein, carbohydrates, fats and fibre are available — cereal grains are important source of mineral elements as well. Macro-elements and trace elements are essential not only for optimal plant growth and development, but also for human and animal nutrition (Underwood and Smitasiri, 1999).

The mineral and trace element contents of plants are known to be affected by the cultivar of plant, soil conditions, weather conditions during the growing season, use of fertilisers and the state of plant maturity at harvest (Pietola and Salo, 2000; Bịlint et al., 2001; Hattori and Chino, 2001).

The demand for organic agriculture and environmentallyfriendly agricultural products is increasing. In this respect it is not known whether and how different agriculture techniques and/or cultivation systems affect the nutrient composition of the final product. Comparison of organically and conventionally grown crops in terms of nutritional value, sensorial quality and food safety, has often highlighted controversial results. As a consequence, a clear link between 
cultivation system and nutritional profile of agricultural products is still missing (Bourn and Prescott, 2002).

Previous studies of micro- and macroelement concentrations in Latvia, since 2000, for example, by Klavins and Vircavs (2001), Gilucis (2007), Cekstere and Osvalde (2013), Nikodemus et al. (2004) and Tabors (2004) have been focused on soil, water quality and air pollution. Stapkevica et al. (2013) studied metal uptake from contaminated soils by some plant species (radish, lettuce and dill). Vincevica-Gaile et al., (2011) determined the geographical distribution of trace and major elements in honey. Only very few studies have been related to food composition, for example, on potatoes (Murniece et al., 2011), cranberries (Osvalde and Karlsons, 2010), honey (Dimins, 2006) and cereal meals (rice meal, buckwheat meal and wheat containing meal), i.e. on cereal mixtures for porridge preparation (Vincevica-Gaile, 2014). The literature lacks information on macroelement and trace element concentrations in cereal grains, depending on type of grain, agronomic practice and climatic conditions.

The aim of the study was to determine the concentrations of macro- and trace elements in cereals cultivated in Latvia.

\section{MATERIALS AND METHODS}

In the State Stende Cereal Breeding Institute, the following cultivated cereal grains were used in the research: rye $(\mathrm{n}=$ $45)$, barley $(n=54)$, spring wheat $(n=27)$, winter wheat $(\mathrm{n}=53)$, triticale $(\mathrm{n}=45)$ and oats $(\mathrm{n}=42)$. Thirteen macro- and trace elements $(\mathrm{Cd}, \mathrm{Pb}, \mathrm{Ni}, \mathrm{Cr}, \mathrm{Al}, \mathrm{Cu}, \mathrm{K}, \mathrm{Na}$, $\mathrm{Mn}, \mathrm{Fe}, \mathrm{Zn}, \mathrm{Mg}, \mathrm{Ca}$ ) were determined in cereal grain samples $(n=266)$ collected in the time period 2011-2013 at the State Stende Cereal Breeding Institute.

Organic field. The soil type was sod-podzolic (PVv), sandy loam and loamy sand. Organic matter content in soil was 20.2-21.6 mg. $\mathrm{kg}^{-1}$, soil $\mathrm{pH}_{\mathrm{KCl}}$ was 5.27-5.89, content of plant available phosphorus $\mathrm{P}_{2} \mathrm{O}_{5} 138-164 \mathrm{mg} \cdot \mathrm{kg}^{-1}$, and potassium $\mathrm{K}_{2} \mathrm{O}$ 130-175 mg. $\mathrm{kg}^{-1}$. The common agronomic practices for organic management were used during the vegetation period.

Conventional field. The soil type in the conventional field was sod-podzolic (PVv), with the following charcteristics: sandy loam, content of organic substances $21-24 \mathrm{mg} \cdot \mathrm{kg}^{-1}$, soil $\mathrm{pH}_{\mathrm{KCl}}$ 5.4-5.8, available phosphorus $\mathrm{P}_{2} \mathrm{O}_{5}$ 137.0-158.8 $\mathrm{mg} \cdot \mathrm{kg}^{-1}$, and potassium $\mathrm{K}_{2} \mathrm{O} 211.0-175.7 \mathrm{mg} \cdot \mathrm{kg}^{-1}$. The experimental treatment consisted of three $\mathrm{N}$ application rates (N80, N120, and N160) in the conventional growing conditions. Complex mineral fertiliser was used as a basic fertiliser at the rate $725 \mathrm{~kg} \cdot \mathrm{ha}^{-1}$ (pure matter $\mathrm{N}-80 \mathrm{~kg} \cdot \mathrm{ha}^{-1}, \mathrm{P}-$ 28.6, $\mathrm{K}-112.4 \mathrm{~kg} \cdot \mathrm{ha}^{-1}$. The $\mathrm{N}$ application was split between two times: part of the $\mathrm{N}$ was applied at the time of sowing and the remaining half at the end of tillering stage (growing stage/GS 29) of the crop. Ammonium nitrate $(\mathrm{N}$ $34 \%$ ) was used a top-fertiliser in the following amount: 40 $\mathrm{kg}$ of $\mathrm{N}$ per ha (N120) and $80 \mathrm{~kg}$ of $\mathrm{N}$ per ha (N160). The treatments were laid out in a randomised complete block design; plot size was $10 \mathrm{~m}^{2}$, four replicates.

Weather conditions. The average air temperature from April to August differs annually. The most significant differences $(p<0.05)$ in temperature were noticed in June: 13 ${ }^{\circ} \mathrm{C}$ in 2011 and 2013 and $17{ }^{\circ} \mathrm{C}$ in 2012 . August mean temperature was similar during the period of study (from 15.5 to $\left.17{ }^{\circ} \mathrm{C}\right)$. Precipitation in July significantly differed $(p<$ 0.05 ) beween years: $35 \mathrm{~mm}$ in 2013 to $165 \mathrm{~mm}$ in 2011. The weather conditions were warmer than the long-term average with a few heavy rainfalls during the growing period of 2011. In August, the air temperature was similar to the long-term average.

Sample preparation. For dry digestion grains were ground and $0.5-1.0 \mathrm{~g}$ was placed into a crucible. The crucible were placed into a muffle furnace with a programmable heating: grain samples were dried for $1 \mathrm{~h}$ at $110^{\circ} \mathrm{C}$; then temperature was increased $\left(50{ }^{\circ} \mathrm{C} \mathrm{h}^{-1}\right)$ until $450{ }^{\circ} \mathrm{C}$ and held for eight hours. After that the crucible was removed from the muffle furnace and cooled down, and $1-3 \mathrm{ml}$ of water was added to the residue in the crucible. This procedure was repeated until light gray or white ash was obtained. Then $6 \mathrm{M}$ $\mathrm{HCl}$ was added and evaporated. The residue was re-dissolved in $25 \mathrm{ml} 0.1 \mathrm{M} \mathrm{HNO}_{3}$ and this solution obtained was used for element determination.

Determination of the mineral and trace elements. Five elements ( $\mathrm{Cd}, \mathrm{Cr}, \mathrm{Al}, \mathrm{Pb}$, and $\mathrm{Ni}$ ) were determined by electrothermal atom absorption spectrometry (ETAA; Perkin Elmer AAnalyst 600, Zeeman background correction was applied) after dry digestion, and eight elements (K, Na, $\mathrm{Zn}, \mathrm{Cu}, \mathrm{Ca}, \mathrm{Mg}, \mathrm{Mn}$ and $\mathrm{Fe}$ ) by flame atom absorption spectrometry (FAAS; Perkin Elmer AAnalyst 800). Absorption measurements were carried out in accordance with manufacturer instructions on wavelengths, lamp and other specifications.

For data analysis the following methods were used: descriptive statistics - indicators of central tendency or location and indicators of variability, non-parametric statistics Kolmogorov-Smirnov test, Kruskal Wallis test, MannWhitney test, and Levene test for equality of variance.

\section{RESULTS}

The $\mathrm{Cd}, \mathrm{Cr}, \mathrm{Cu}$, and $\mathrm{Zn}$ concentrations were very variable in barley (respectively, 0.0011-0.0670 mg. $\mathrm{kg}^{-1}$; 0.021-.921 $\mathrm{mg} \cdot \mathrm{kg}^{-1} ; 1.71-5.9 \mathrm{mg} \cdot \mathrm{kg}^{-1}$; and $16-53 \mathrm{mg} \cdot \mathrm{kg}^{-1}$ ), while the lowest ranges in concentrations occurred in spring wheat (respectively, 0.008-0.041 $\mathrm{mg} \cdot \mathrm{kg}^{-1} ; 0.053-0.295 \mathrm{mg} \cdot \mathrm{kg}^{-1}$; $\left.3.1-5.8 \mathrm{mg} \cdot \mathrm{kg}^{-1} ; 18-35 \mathrm{mg} \cdot \mathrm{kg}^{-1}\right)$. The highest $\mathrm{Cd}$ concentration was in winter wheat $0.0306 \pm 0.0124 \mathrm{mg} \cdot \mathrm{kg}^{-1}$, the highest $\mathrm{Cr}, \mathrm{Cu}$, and $\mathrm{Zn}$ concentrations were in oats (respectively, $0.490 \pm 0.726 \mathrm{mg} \cdot \mathrm{kg}^{-1} ; 5.65 \pm 4.954 \mathrm{mg} \cdot \mathrm{kg}^{-1}$, and $\left.28.680 \pm 4.710 \mathrm{mg} \cdot \mathrm{kg}^{-1}\right)$. The lowest $\mathrm{Cd}$ concentration was in barley $0.0095 \pm 0.0101 \mathrm{mg} \cdot \mathrm{kg}^{-1}$, while the lowest $\mathrm{Cr}, \mathrm{Cu}$, and $\mathrm{Zn}$ concentrations were in rye (respectively, $0.086 \pm$ 
$0.066 \mathrm{mg} \cdot \mathrm{kg}^{-1} ; 1.915 \pm 0.907 \mathrm{mg} \cdot \mathrm{kg}^{-1} ;$ and $18.140 \pm 4.876$ $\left.\mathrm{mg} \cdot \mathrm{kg}^{-1}\right)$. The statistics of the $\mathrm{Cd}, \mathrm{Cr}, \mathrm{Cu}$, and $\mathrm{Zn}$ concentration in cereal grains are shown in Table 1.

Table 1

STATISTICAL INDICATORS OF THE MACRO-ELEMENTS AND TRACE ELEMENTS CONCENTRATION IN CEREAL GRAINS, $\mathrm{mg} \cdot \mathrm{kg}^{-1}$

\begin{tabular}{|c|c|c|c|c|c|c|c|}
\hline $\begin{array}{c}\text { Ele- } \\
\text { ments }\end{array}$ & $\begin{array}{l}\text { Statistical } \\
\text { indicators }\end{array}$ & Barley & Oats & $\begin{array}{c}\text { Spring } \\
\text { wheat }\end{array}$ & $\begin{array}{l}\text { Winter } \\
\text { wheat }\end{array}$ & Triticale & Rye \\
\hline 1 & 2 & 3 & 4 & 5 & 6 & 7 & 8 \\
\hline \multirow[t]{6}{*}{$\mathrm{Cd}$} & $\mathrm{N}$ & 54 & 42 & 27 & 53 & 45 & 45 \\
\hline & Mean & 0.0095 & 0.0180 & 0.0231 & 0.0306 & 0.0206 & 0.0132 \\
\hline & Median & 0.0048 & 0.0130 & 0.0240 & 0.0290 & 0.0180 & 0.0080 \\
\hline & SD & 0.0101 & 0.0146 & 0.0084 & 0.0124 & 0.0105 & 0.0124 \\
\hline & Minimum & 0.0011 & 0.0045 & 0.0080 & 0.0045 & 0.0045 & 0.00450 \\
\hline & Maximum & 0.0670 & 0.0550 & 0.0410 & 0.0600 & 0.0540 & 0.05600 \\
\hline \multirow[t]{5}{*}{$\mathrm{Pb}$} & Mean & 0.0234 & 0.0343 & 0.0346 & 0.0218 & 0.0220 & 0.0210 \\
\hline & Median & 0.0180 & 0.0240 & 0.0320 & 0.0160 & 0.0180 & 0.0200 \\
\hline & SD & 0.0206 & 0.0319 & 0.0208 & 0.0170 & 0.0141 & 0.0121 \\
\hline & Minimum & 0.0090 & 0.0095 & 0.0095 & 0.0095 & 0.0095 & 0.0095 \\
\hline & Maximum & 0.1400 & 0.1510 & 0.0890 & 0.0970 & 0.0620 & 0.0540 \\
\hline \multirow[t]{5}{*}{$\mathrm{Cr}$} & Mean & 0.2150 & 0.4900 & 0.1307 & 0.1028 & 0.1384 & 0.0861 \\
\hline & Median & 0.1700 & 0.2150 & 0.1180 & 0.0950 & 0.0920 & 0.0680 \\
\hline & SD & 0.1655 & 0.7263 & 0.0639 & 0.0647 & 0.11902 & 0.06643 \\
\hline & Minimum & 0.021 & 0.005 & 0.053 & 0.026 & 0.005 & 0.005 \\
\hline & Maximum & 0.921 & 3.210 & 0.295 & 0.425 & 0.529 & 0.334 \\
\hline \multirow[t]{5}{*}{$\mathrm{Ni}$} & Mean & 0.7105 & 1.0888 & 0.2449 & 0.1065 & 0.1184 & 0.0982 \\
\hline & Median & 0.104 & 0.8515 & 0.131 & 0.091 & 0.083 & 0.084 \\
\hline & $\mathrm{SD}$ & 1.5307 & 0.6482 & 0.3152 & 0.0532 & 0.1373 & 0.0451 \\
\hline & Minimum & 0.045 & 0.171 & 0.045 & 0.025 & 0.031 & 0.045 \\
\hline & Maximum & 9.014 & 2.400 & 1.470 & 0.229 & 0.808 & 0.268 \\
\hline \multirow[t]{5}{*}{$\mathrm{Al}$} & Mean & 3.242 & 5.6460 & 3.675 & 5.212 & 2.964 & 1.915 \\
\hline & Median & 2.98 & 3.835 & 2.82 & 2.12 & 2.46 & 1.72 \\
\hline & $\mathrm{SD}$ & 2.087 & 4.954 & 2.231 & 9.933 & 2.217 & 0.907 \\
\hline & Minimum & 0.89 & 0.62 & 1.42 & 0.45 & 0.45 & 0.45 \\
\hline & Maximum & 12.72 & 17.28 & 11.79 & & 11.8 & 3.68 \\
\hline \multirow[t]{5}{*}{$\mathrm{Cu}$} & Mean & 3.607 & 3.794 & 4.471 & 3.987 & 4.225 & 3.478 \\
\hline & Median & 3.50 & 3.735 & 4.55 & 3.90 & 4.30 & 3.30 \\
\hline & SD & 0.863 & 0.577 & 0.670 & 0.831 & 0.804 & 0.684 \\
\hline & Minimum & 1.71 & 2.70 & 3.10 & 2.60 & 2.60 & 2.10 \\
\hline & Maximum & 5.90 & 5.00 & 5.80 & 5.78 & 6.00 & 4.83 \\
\hline \multirow[t]{5}{*}{ K } & Mean & 4431.6 & 3803.4 & 5115.5 & 4004.3 & 5244.4 & 4510.6 \\
\hline & Median & 4430 & 3833 & 5270 & 4120 & 5520 & 4670 \\
\hline & $\mathrm{SD}$ & 459.5 & 520.2 & 683.6 & 789.8 & 874.0 & 868.7 \\
\hline & Minimum & 3494 & 2500 & 3480 & 1940 & 3450 & 2320 \\
\hline & Maximum & 5260 & 4790 & 6718 & 5640 & 6813 & 6164 \\
\hline \multirow[t]{5}{*}{$\mathrm{Na}$} & Mean & 107.4 & 83.9 & 58.4 & 51.8 & 91.8 & 84.5 \\
\hline & Median & 64 & 63.5 & 29.5 & 30 & 95 & 43 \\
\hline & $\mathrm{SD}$ & 109.7 & 77.0 & 70.7 & 52.1 & 76.1 & 107.4 \\
\hline & Minimum & 15.8 & 10.8 & 17.0 & 10.1 & 10.2 & 10.3 \\
\hline & Maximum & 387 & 382 & 297 & 249 & 296 & 629 \\
\hline \multirow[t]{3}{*}{$\mathrm{Ca}$} & Mean & 375.6 & 766.8 & 436.0 & 473.3 & 412.0 & 394.6 \\
\hline & Median & 339 & 686 & 405 & 460 & 371 & 373 \\
\hline & SD & 100.5 & 224.7 & 93.7 & 142.7 & 140.6 & 81.7 \\
\hline
\end{tabular}

Table 1 (continued)

\begin{tabular}{|c|c|c|c|c|c|c|c|}
\hline 1 & 2 & 3 & 4 & 5 & 6 & 7 & 8 \\
\hline & Minimum & 260 & 475 & 302 & 216 & 215 & 243 \\
\hline & Maximum & 688 & 1272 & 684 & 815 & 1046 & 596 \\
\hline \multirow{5}{*}{ Mn } & Mean & 12.4 & 38.8 & 26.2 & 27.1 & 24.7 & 22.6 \\
\hline & Median & 12 & 39 & 26 & 26 & 23.6 & 21 \\
\hline & SD & 2.7 & 10.1 & 6.7 & 6.6 & 8.1 & 5.6 \\
\hline & Minimum & 7 & 20 & 14 & 15 & 13 & 13 \\
\hline & Maximum & 18 & 54 & 37 & 43 & 44 & 32 \\
\hline \multirow[t]{5}{*}{$\mathrm{Mg}$} & Mean & 1157.1 & 1365.5 & 1334.3 & 1230.1 & 1262.6 & 978.0 \\
\hline & Median & 1172 & 1301 & 1301 & 1193 & 1217 & 975 \\
\hline & SD & 89.3 & 120.3 & 120.4 & 253.8 & 212.7 & 100.2 \\
\hline & Minimum & 907 & 1070 & 1149 & 539 & 1015 & 770 \\
\hline & Maximum & 1385 & 1630 & 1626 & 1945 & 1887 & 1165 \\
\hline \multirow[t]{5}{*}{$\mathrm{Fe}$} & Mean & 37.8 & 43.6 & 26.0 & 29.9 & 27.5 & 32.1 \\
\hline & Median & 36.6 & 44.5 & 23.8 & 31 & 26.8 & 31.4 \\
\hline & SD & 8.5 & 6.8 & 8.8 & 8.4 & 4.5 & 4.5 \\
\hline & Minimum & 25 & 28 & 14 & 15 & 17 & 25 \\
\hline & Maximum & 66 & 59 & 54 & 50 & 40 & 45 \\
\hline \multirow[t]{5}{*}{$\mathrm{Zn}$} & Mean & 26.4 & 28.7 & 22.8 & 22.3 & 24.1 & 18.1 \\
\hline & Median & 23.9 & 28.2 & 21.9 & 20 & 22 & 17 \\
\hline & SD & 8.9 & 4.7 & 4.9 & 6.6 & 6.1 & 4.9 \\
\hline & Minimum & 16 & 19 & 18 & 15 & 17 & 11 \\
\hline & Maximum & 53 & 40 & 35 & 44 & 38 & 35 \\
\hline
\end{tabular}

$\mathrm{SD}$, standard deviation

$\mathrm{Cd}, \mathrm{Cr}, \mathrm{Cu}$, and $\mathrm{Zn}$ concentrations differed significantly between the type of grains $(p<0.0010)$, shown by the Kruskal Wallis test (respectively, $\chi^{2}=103.486, p=0 ; \chi^{2}=72.837$, $p=0, \chi^{2}=41.119, p=0$, and $\left.\div^{2}=70.233, p=0\right)$. Cd concentration differed statistically significantly in barley where it was lowest and in oats, in spring wheat, winter wheat, triticale, rye; it was proved by the results of the MannWhitney tests $(p<0.05)$. Cr concentration differed statistically significantly in oats and in barley, spring wheat, winter wheat, triticale, rye; $\mathrm{Cr}$ concentration differed statistically significantly also in barley and in spring wheat, winter wheat, triticale, rye, also in spring wheat and in winter wheat, rye, and in winter wheat and in rye, in triticale and in rye; it was proved by the results of the Mann-Whitney tests $(p<0.05)$. $\mathrm{Cu}$ concentration differed statistically significantly in barley and in spring wheat, winter wheat, triticale, also in oats and in spring wheat, triticale, rye, and in spring wheat and in winter wheat, rye, in winter wheat and in rye; it was proved by the results of the Mann-Whitney tests $(p<$ $0.05)$. Zn concentration differed statistically significantly in oats and in barley, spring wheat, winter wheat, triticale, rye, also in barley and in winter wheat, rye, in spring wheat and in rye, in winter wheat and in rye, in triticale and in rye; it was proved by the results of the Mann-Whitney tests $(p<$ $0.05)$.

The range in $\mathrm{Pb}$ concentration was highest in oats $(0.0095-$ $\left.0.1510 \mathrm{mg} \cdot \mathrm{kg}^{-1}\right)$ and lowest in rye $(0.0095-0.0540$ $\left.\mathrm{mg} \cdot \mathrm{kg}^{-1}\right)$. The highest $\mathrm{Pb}$ concentration was in spring wheat $0.0346 \pm 0.0208 \mathrm{mg} \cdot \mathrm{kg}^{-1}$ and the lowest $\mathrm{Pb}$ concentration in 
rye $0.0210 \pm 0.0121 \mathrm{mg} \cdot \mathrm{kg}^{-1}$ (see Table 1$) . \mathrm{Pb}$ concentrations significantly differed between cereal crops (Kruskal Wallis test, $\left.\chi^{2}=13.395, p=0.020\right)$. The $\mathrm{Pb}$ concentration differed statistically significant in rye and in spring wheat, in triticale and in spring wheat, in winter wheat and in spring wheat; it was proved by the results of the MannWhitney tests $(p<0.05)$.

The widest range in $\mathrm{Ni}$ concentration was in barley $\left(0.045-9.014 \mathrm{mg} \cdot \mathrm{kg}^{-1}\right)$ and the lowest in winter wheat $\left(0.025-0.229 \mathrm{mg} \cdot \mathrm{kg}^{-1}\right)$. The highest $\mathrm{Ni}$ concentration was in oats $\left(1.109 \pm 0.648 \mathrm{mg} \cdot \mathrm{kg}^{-1}\right)$ and the lowest in rye $(0.098 \pm$ $0.045 \mathrm{mg} \cdot \mathrm{kg}^{-1}$, Table 1$)$. Ni concentration significantly differed between ceral crops (Kruskal Wallis test $\chi^{2}=97.071$, $p=0$ ). The Ni concentration differed statistically significant in oats and in barley, spring wheat, winter wheat, triticale, rye, the $\mathrm{Ni}$ concentration differed statistically significant also in barley and in winter wheat, triticale, and also in spring wheat and in winter wheat, triticale, rye; it was proved by the results of the Mann-Whitney tests $(p<0.05)$.

The widest range in $\mathrm{Ca}$ concentration was in triticale (215-1046 $\left.\mathrm{mg} \cdot \mathrm{kg}^{-1}\right)$ and the lowest in rye (243-596 $\left.\mathrm{mg} \cdot \mathrm{kg}^{-1}\right)$. The highest Ca concentration was in oats $(766.75$ $\left.\pm 224.69 \mathrm{mg} \cdot \mathrm{kg}^{-1}\right)$ and the lowest in barley $(375.60 \pm$ $100.50 \mathrm{mg} \cdot \mathrm{kg}^{-1}$; Table 1). Ca concentration significantly differed between cereal crops (Kruskal Wallis test $\chi^{2}=$ 108.043, $p=0$ ). The Ca concentration differed statistically significant in barley and in oats, spring wheat, winter wheat, and also in oats and in spring wheat, winter wheat, triticale, rye, and in spring wheat and in rye, in winter wheat and in triticale, rye; it was proved by the results of the MannWhitney tests $(\mathrm{p}<0.05)$.

The widest range of Mn concentration was in oat (20-54 $\left.\mathrm{mg} \cdot \mathrm{kg}^{-1}\right)$ and the lowest in barley $\left(7-18 \mathrm{mg} \cdot \mathrm{kg}^{-1}\right)$. The highest Mn concentration was in oats $\left(38.760 \pm 10.140 \mathrm{mg} \cdot \mathrm{kg}^{-1}\right)$ and the lowest in barley $\left(12.390 \pm 2.660 \mathrm{mg} \cdot \mathrm{kg}^{-1}\right.$; Table 1). Mn concentration significantly differed between cereal crops (Kruskal Wallis test $\chi^{2}=157.175, \mathrm{p}=0$ ). Mn concentration differed statistically significantly in barley and in oats, spring wheat, winter wheat, triticale, rye, and also in oats and in spring wheat, winter wheat, triticale, rye, and in spring wheat and in rye, in winter wheat and in rye; it was proved by the results of the Mann-Whitney tests $(p<0.05)$.

The widest range of $\mathrm{Mg}$ concentration was in winter wheat $\left(539-1945 \mathrm{mg} \cdot \mathrm{kg}^{-1}\right)$ and the lowest in rye $(770-1165$ $\left.\mathrm{mg} \cdot \mathrm{kg}^{-1}\right)$. The highest $\mathrm{Mg}$ concentration was in oats $\left(1365.54 \pm 120.26 \mathrm{mg} \cdot \mathrm{kg}^{-} 1\right)$ and the lowest in rye $(977.98 \pm$ $100.16 \mathrm{mg} \cdot \mathrm{kg}^{-1}$, Table 1$)$. Mg concentration significantly differed between cereal crops (Kruskal Wallis test $\left(\chi^{2}=\right.$ $119.829, \mathrm{p}=0)$. Mg concentration differed statistically significantly in barley and in oats, spring wheat, triticale, rye, and also in oats and in winter wheat, triticale, rye, and in spring wheat and in winter wheat, triticale, rye, in winter wheat and in rye, in triticale and in rye; it was proved by the results of the Mann-Whitney tests $(p<0.05)$.

Fe concentration had the widest range in barley (25-66 $\left.\mathrm{mg} \cdot \mathrm{kg}^{-1}\right)$ and the lowest in rye $\left(25-45 \mathrm{mg} \cdot \mathrm{kg}^{-1}\right)$. The high- est $\mathrm{Fe}$ concentration occurred in oats $(43.550 \pm 6.756$ $\left.\mathrm{mg} \mathrm{kg}^{-1}\right)$ and the lowest in spring wheat $(26.000 \pm 8.839$ $\mathrm{mg} \cdot \mathrm{kg}^{-1}$, Table 1). Fe concentration significantly differed between cereal crops (Kruskal Wallis test $\chi^{2}=114.964, p=$ $0)$. The Fe concentration differed statistically significant in barley and in oats, spring wheat, triticale, rye, and also in oats and in spring wheat, winter wheat, triticale, rye, and in spring wheat and in winter wheat, rye, in winter wheat and in triticale, in triticale and in rye; it was proved by the results of the Mann-Whitney tests $(p<0.05)$.

The widest $\mathrm{Al}$ concentration range occurred in winter wheat $\left(0.45-46.01 \mathrm{mg} \cdot \mathrm{kg}^{-1}\right)$ and the lowest in rye $(0.45-3.68$ $\left.\mathrm{mg} \cdot \mathrm{kg}^{-1}\right)$. The highest $\mathrm{Al}$ concentration occurred in oats $\left(5.650 \pm 4.954 \mathrm{mg} \cdot \mathrm{kg}^{-1}\right)$ and the lowest in rye $(1.915 \pm$ $0.907 \mathrm{mg} \cdot \mathrm{kg}^{-1}$; Table 1). Al concentration significantly differed between cereal crops (Kruskal Wallis test $\chi^{2}=24.990$, $p=0$ ). Al concentration differed statistically significant in oats and in rye, in barley and in winter wheat, rye, also in spring wheat and in winter wheat, rye, in triticale and in rye; it was proved by the results of the Mann-Whitney tests $(p<$ $0.05)$.

The widest $\mathrm{Na}$ concentration range occurred in rye, (10.3-629 $\mathrm{mg} \cdot \mathrm{kg}^{-1}$ ) and the lowest in winter wheat (10.1-296 mg. $\left.\mathrm{kg}^{-1}\right)$. The highest $\mathrm{Na}$ concentration was in barley $\left(107.41 \pm 109.73 \mathrm{mg} \cdot \mathrm{kg}^{-1}\right)$ and the lowest in winter wheat $\left(51.78 \pm 52.14 \mathrm{mg} \cdot \mathrm{kg}^{-1}\right.$; Table 1$)$. Na concentration did not significantly differ between cereal crops (Kruskal Wallis test $\chi^{2}=10.798, p>0.05$ ).

$\mathrm{K}$ concentration had the widest range in rye (2320-6164 $\left.\mathrm{mg} \cdot \mathrm{kg}^{-1}\right)$ and the lowest in barley $\left(3494-5260 \mathrm{mg} \cdot \mathrm{kg}^{-1}\right)$. The highest $\mathrm{K}$ concentration was in triticale (5244.40 \pm $\left.873.98 \mathrm{mg} \cdot \mathrm{kg}^{-1}\right)$ and the lowest in oats $(3803.38 \pm 520.12$ $\left.\mathrm{mg} \cdot \mathrm{kg}^{-1}\right)$. K concentration significantly differed between cereal crops (Kruskal Wallis test $\chi^{2}=84.627, p=0$ ). The K concentration differed statistically significantly in barley and in oats, spring wheat, winter wheat, triticale, also in oats and in spring wheat, triticale, rye, and in spring wheat and in winter wheat, rye, in winter wheat and in triticale rye, in triticale and in rye; it was proved by the results of the Mann-Whitney tests $(p<0.05)$.

The $\mathrm{Cd}, \mathrm{Pb}, \mathrm{Ni}, \mathrm{Al}, \mathrm{Cu}, \mathrm{K}, \mathrm{Na}, \mathrm{Mn}, \mathrm{Mg}$, and $\mathrm{Zn}$ concentrations differed significantly within harvesting year $(p<$ 0.05). The $\mathrm{Cd}, \mathrm{Ni}, \mathrm{Mn}$, and $\mathrm{Zn}$ concentrations significantly differed between years, being higher in 2011 (Mann-Whitney test, $p<0.05$ ). In 2011, the concentrations of $\mathrm{Cd}, \mathrm{Ni}$, and $\mathrm{Zn}$ were higher than in 2012 and 2013 while the $\mathrm{Mn}$ concentration was lower in 2011. Pb, Mg, Fe, and Al concentrations in cereal grains significantly differed between years (Mann-Whitney test, $p<0.05$ ). The $\mathrm{Cu}$ and $\mathrm{Ca}$ concentrations were significantly lower in 2012 (Mann-Whitney tests $p<0.001$ ) than in 2011 and 2013. Na and K concentrations in cereal grains significantly differed in 2013 (Mann-Whitney tests $p<0.01$ ): lower Na concentration and higher $\mathrm{K}$ concentration. The arithmetic means and standard deviations of the macro-element and trace element concentrations in cereal grains, in 2011, 2012, and 2013 are shown in Table 2. 
Table 2

MEANS AND STANDARD DEVIATIONS OF MACRO-ELEMENT AND TRACE ELEMENT CONCENTRATIONS IN CEREAL GRAIN CROPS IN 2011, 2012, 2013, $\mathrm{mg} \cdot \mathrm{kg}^{-1}(\mathrm{n}=266)$

\begin{tabular}{lcccc}
\hline Elements & 2011 & 2012 & 2013 \\
\hline $\mathrm{Cd}$ & $0.0235 \pm 0.0146^{*}$ & $0.0120 \pm 0.0094$ & $0.0131 \pm 0.0128$ \\
$\mathrm{~Pb}$ & $0.0440 \pm 0.0289^{*}$ & $0.0208 \pm 0.0098^{*}$ & $0.0138 \pm 0.0078^{*}$ \\
$\mathrm{Cr}$ & $0.222 \pm 0.167$ & $0.341 \pm 0.692$ & $0.177 \pm 0.169$ \\
$\mathrm{Ni}$ & $0.854 \pm 0.820 *$ & $0.286 \pm 0.485$ & $0.213 \pm 0.257$ \\
$\mathrm{Al}$ & $6.32 \pm 4.31 *$ & $2.92 \pm 0.91 *$ & $1.44 \pm 0.74 *$ \\
$\mathrm{Cu}$ & $4.10 \pm 0.84$ & $3.52 \pm 0.60^{* * *}$ & $3.95 \pm 0.74$ \\
$\mathrm{~K}$ & $4436 \pm 654$ & $4361 \pm 718$ & $4673 \pm 888^{* *}$ \\
$\mathrm{Na}$ & $121.6 \pm 101.6$ & $87.9 \pm 71.8$ & $17.4 \pm 6.0 * *$ \\
$\mathrm{Ca}$ & $618 \pm 291$ & $411 \pm 129 * * *$ & $477 \pm 139$ \\
$\mathrm{Mn}$ & $23 \pm 12^{*}$ & $24 \pm 12$ & $28 \pm 13$ \\
$\mathrm{Mg}$ & $1255 \pm 145^{*}$ & $1135 \pm 165^{*}$ & $1281 \pm 200^{*}$ \\
$\mathrm{Fe}$ & $34 \pm 11 *$ & $36 \pm 10^{*}$ & $36 \pm 7 *$ \\
$\mathrm{Zn}$ & $29 \pm 7 *$ & $22 \pm 6$ & $22 \pm 5$ \\
$* p<0.05 ; * * p<0.01 ; * * * p<0.001$ &
\end{tabular}

\section{DISCUSSION}

From a nutritional point of view, attention mainly has been focused on essential trace elements, e.g., $\mathrm{Fe}, \mathrm{Ca}, \mathrm{Cu}$, and $\mathrm{Zn}$ (Kashian and Fathivand, 2015). Another important issue is food safety, which is a major public health concern worldwide and food consumption has been identified as the major pathway for human exposure to environmental contaminants; accounting for over $90 \%$ of intake compared to inhalation or dermal routes of exposure (Fries, 1995). Micronutrients may become harmful when their ingestion rates are too high. In contrast, trace elements such as $\mathrm{Cd}$ and $\mathrm{Pb}$ are well known as toxic if their intake through ingestion or inhalation is excessive (Al-Gahri and Almussali, 2008). The levels of some elements can vary in a large scale.

Shar et al (2013) reported mineral element and trace element concentrations in barley cultivars of Pakistan that had higher concentrations comparing to barley cultivated in Latvia. These differences might be due to growing area, climate, cultivation practise and cultivar, as significant difference due to these factors were shown within Pakistan.

Al-Gahri and Almussali (2008) reported mineral (Fe, Zn, $\mathrm{Mn}, \mathrm{Cu}, \mathrm{Cd}$, and $\mathrm{Pb}$ ) concentrations in wheat cultivated in three Yemen regions. In comparison with levels in wheat samples cultivated in Latvia, all minerals had higher concentration, excepting $\mathrm{Zn}$, which was in twice higher concentration in Latvian wheat samples. These differences might be explained by climate - wheat in Yemen is mainly cultivated in northern regions at altitude more than $2000 \mathrm{~m}$ above sea level or elsewhere with irrigation (Al-Gahri and Almussali, 2008).

Sager and Hoesch (2005) determined $\mathrm{Ca}, \mathrm{Fe}, \mathrm{Mn}, \mathrm{Cu}, \mathrm{S}$, and $\mathrm{P}$ concentrations in various cereal grains (wheat, rye, barely, and maize) of Austria. Fe concentration in barley was in the range from 31.1 to $54.1 \mathrm{mg} \cdot \mathrm{kg}^{-1}$, in wheat samples from 19.1 to $44.5 \mathrm{mg} \cdot \mathrm{kg}^{-1}$ and in rye from 15.6 to 36.8 $\mathrm{mg} \cdot \mathrm{kg}^{-1}$, which are similar to the ranges of these elements in Latvia. $\mathrm{Cu}$ and $\mathrm{Mn}$ concentrations were also similar, excepting Mn concentration in rye samples, which was higher in Latvia. Concentrations of $\mathrm{Zn}$ in grains cultivated in Austria were higher than in Latvia, except for wheat samples, which had similar concentrations.

Ciołek et al. (2012) determined macro- and trace element concentrations $(\mathrm{K}, \mathrm{Ca}, \mathrm{Mg}, \mathrm{Cu}, \mathrm{Mn}, \mathrm{Fe}$ and $\mathrm{Zn}$ ) in oats, wheat, hulled barley, and hull-less barley cultivated in Poland. Concentrations of $\mathrm{K}$ in barley and oats were similar to those in Latvia, but lower in wheat. Ca concentrations were higher in oats and barley in Latvia, $\mathrm{Mg}$ concentrations were higher in all studied grains cultivated in Latvia, $\mathrm{Cu}$ concentration was twice as higher in wheat samples from Latvia, and $\mathrm{Mn}$ concentration was twice as higher in oats. Fe and $\mathrm{Zn}$ concentrations were similar between the countries.

Kan (2015) determined macro- and trace element concentrations (K, P, Ca, Mg, Fe, Mn, $\mathrm{Ni}, \mathrm{Pb}, \mathrm{Cr}, \mathrm{Zn}, \mathrm{Cu}$, and $\mathrm{Na}$ ) in wheat, rye, oat, barley and triticale (cultivated in Turkey). $\mathrm{K}$ concentration was the highest in wheat samples $(6490$ $\mathrm{mg} \cdot \mathrm{kg}^{-1}$ ), while in the present research the highest $\mathrm{K}$ concentration was in triticale $\left(5244.4 \mathrm{mg} \cdot \mathrm{kg}^{-1}\right)$. Ca concentration was the highest in wheat samples $\left(1133 \mathrm{mg} \cdot \mathrm{kg}^{-1}\right)$, which was much higher than in cereal crops cultivated in Latvia. The highest $\mathrm{Ca}$ concentration was observed in oats $\left(803.14 \mathrm{mg} \cdot \mathrm{kg}^{-1}\right)$. Also $\mathrm{Mg}$ concentration in cereal grains of Turkey was the highest in wheat $\left(2766 \mathrm{mg} \cdot \mathrm{kg}^{-1}\right)$, while in Latvia it was highest in oats $\left(1361 \mathrm{mg} \cdot \mathrm{kg}^{-1}\right)$. In Turkey, Na concentration was the highest in wheat $\left(19 \mathrm{mg} \cdot \mathrm{kg}^{-1}\right)$, and $\mathrm{Zn}$ concentration in rye $\left(28 \mathrm{mg} \cdot \mathrm{kg}^{-1}\right)$ and oats $(28.68$ $\left.\mathrm{mg} \cdot \mathrm{kg}^{-1}\right)$. In general, in Turkey wheat grains were richest in micro- and trace elements (Kan, 2015), while in Latvia oat grains had the highest levels.

In conclusion, the highest concentrations of the macro-element and trace elements were found in oat grains, while the lowest were observed in rye. There were large differences in macro-element and trace element concentrations between Latvia and Asian countries, while the level were rather similar to those in Austria, Poland, and Turkey.

The determined element concentrations have supplemented the state database with information on composition of food and its raw materials in Latvia. The observed concentrations did not exceed admissible upper limits. For food and nutrition scientists, the obtained data will expand the opportunity to evaluate the content of the examined elements in grain products, and dietary consumption (bioavailability) of macro-elements and trace elements.

The obtained results will be provided to the National Food Composition database - information will be available for stakeholders involved in the area of nutrition and health making policy.

\section{ACKNOWLEDGMENTS}

The authors acknowledge financial support from the European Social Fund project No. 2013/0072/1DP/1.1.1.2.0/13/ APIA/VIAA/032. 


\section{REFERENCES}

Al-Gahri, M. A., Almussali, M. S. (2008). Microelement content of locally produced and imported wheat grains in Yemen. E-Journal Chem., 5 (4), 838-843.

Anonymous (2015). European Commission, Agriculture and Rural Development, Cereals, oilseeds and protein crops, rice. http://ec.europa.eu/agriculture/cereals/index_en.htm (accessed 20 February 2015).

Awika, J. M. (2011). Major cereal grains production and use around the world. In: Awika, J. M., Pirronen, W., Bean, S. (eds.). Cereal Science: Implications to Food Processing and Health Promotion. ACS Symposium Series. American Chemical Society, Washington, DC, pp 1-13.

Bịlint, A. F., Kovacs, G., Erdei, L. J. (2001). Comparison of the Cu, Zn, Fe, $\mathrm{Ca}$ and $\mathrm{Mg}$ contents of the grains of wild, ancient and cultivated wheat species. Cereal Res. Commun., 29, 375-382.

Bourn, D., Prescott, J. (2002). A comparison of the nutritional value, sensory qualities, and food safety of organically and conventionally produced foods. Critical Rev. Food Sci. Nutr., 42, 1-34.

Cekstere, G., Osvalde, A. (2013). A study of chemical characteristics of soil in relation to street trees status in Riga (Latvia). Urban Forestry Urban Greening, 12 (1), 69-78.

Ciołek, A., Makarska, E., Wesołowski, M., Cierpiała, R. (2012). Content of selected nutrients in wheat, barely and oat grains from organic and conventional farming. J. Elementol., 2, 181-189.

Dewettinck, K., van Bockstaele, F., Kühne, B., van de Walle, D., Courtens, T. M., Gellynck, X. (2008). Nutritional value of bread: Influence of processing, food interaction and consumer perception. J. Cereal Sci., 48, 243-257.

Dimiņš, F. (2006). Medus kvalitātes novērtēěsanas rādītāji. Disertācijas darbs [Assessment Parameters of Honey Quality. Doctoral thesis]. LLU, Jelgava, 85 lpp. (in Latvian). Available at: http://llufb.llu.lv/dissertation-summary/food/Kopsavilkums-Fredijs-Dimins.pdf (accessed 5 July 2015).

Doxastakis, G., Zafiriadis, I., Irakli, M., Marlani, H., Tananaki, C. (2002). Lupin, soya and triticale addition to wheat flour doughs and their effect on rheological properties. Food Chem., 77 (2), 219-227.

Fries, G. F. (1995). A review of the significance of animal food products as potential pathways of human exposures to dioxins. J. Animal Sci., 73 (6), 1639-1650.

Gilucis, A. (2007). Mikro- un makroelementu satura un izplatības likumsakarības Latvijas augšn,u virsējos horizontos. Disertācijas darbs [Relevancies of Content and Distribution of Trace and Major Elements in the Latvian Topsoils. Doctoral thesis]. LU, Rīga, 88 lpp. (in Latvian). Available at: http://www3.acadlib.lv/greydoc/Gilucis_disertacija/Gilucis.pdf (accessed 5 July 2015)

Hattori, H., Chino, M. (2001). Growth, cadmium, and zinc contents of wheat grown on various soils enriched with cadmium and zinc. Devel. Plant Soil Sci., 92, 462-463.

Kan, A. (2015). Characterizaton of the fatty acid and mineral composition of selected cereal cultivars from Turkey. Rec. Nat. Prod. J., 9 (1), 124-134.

Kashian, S., Fathivand, A. A. (2015). Estimated daily intake of $\mathrm{Fe}, \mathrm{Cu}, \mathrm{Ca}$ and $\mathrm{Zn}$ through common cereals in Tehran, Iran. Food Chem., 176, 193-196.
Klavins, M., Vircavs, M. (2001). Metals in sediments of inland waters of Latvia. Boreal Environ. Res., 6 (4), 297-306.

Lombardi-Boccia, G., Aguzzi, A., Cappelloni, M., Di Lullo, G., Lucarini, M. (2003). Total-diet study: Dietary intakes of macro elements and trace elements in Italy. Brit. J. Nutr., 90, 1117-1121.

McKevith, B. (2004). Nutritional aspects of triticale. British Nutrition Foundation. Nutr. Bull., 29, 111-142.

Murniece, I., Karklina, D., Galoburda, R., Santare, D., Skrabule, I., Costa, H. S. (2011). Nutritional composition of freshly harvested and stored Latvian potato (Solanum tuberosum L.) varieties depending on traditional cooking methods. J. Food Compos. Anal., 24 (4-5), 699-710.

Nikodemus, O., Brumelis, G., Tabors, G., Lapina, L., Pope, S. (2004) Monitoring of air pollution in Latvia between 1990 and using moss. J. Atmosph. Chem., 49, 521-531

Osvalde, A., Karlsons, A. (2010). Evaluation of the nutrient status of American cranberry in Latvia during 2001-2007. Acta Horticult., 868, 213-218.

Pietola, L., Salo, T. (2000). Response of P, K, Mg and $\mathrm{NO}_{3}-\mathrm{N}$ contents of carrots to irrigation, soil compaction, and nitrogen fertilization. Agricult. Food Sci. Finland, 9, 319-331.

Poutanen, K. (2012). Past and future of cereal grains as food for health Trends Food Sci. Technol., 25, 58-62.

Rakha, A., Åman, P., Andersson, R. (2011). Dietary fibre in triticale grain: Variation in content, composition, and molecular weight distribution of extractable components. J. Cereal Sci., 54 (3), 324-331.

Sager, M., Hoesch, J. (2005). Macro- and micro element levels in cereals grown in lower Austria. J. Central Eur. Agricult., 6, 4, 461-472.

Shar, G. Q., Kazi, T. G., Jatoi, W. B., Makhija, P. M., Sahito, S. B., Shar, A. H., Soomro, F. M. (2013). Determination of heavy metals in eight barley cultivars collected from wheat research station Tandojam, Sindh, Pakistan. Pakistan J. Anal. Environ. Chem., 14 (1), 47-53.

Stapkevica, M., Vincevica-Gaile, Z., Klavins, M. (2013). Metal uptake from contaminated soils by some plant species — radish, lettuce, dill. Res. Rural Devel., 1, 43-49.

Tabors, G., Brumelis, G., Lapina, L., Pospelova, G., Nikodemus, O. (2004). Changes in element concentrations in moss segments after cross-transplanting between a polluted and non-polluted site. J. Atmosph. Chem., 49, 191-197.

Underwood, B. A., Smitasiri, S. (1999). Micronutrient malnutrition: Policies and programs for control and their implications. Annu. Rev. Nutr., 19, 303-324.

Vincevica-Gaile, Z., Klavins, M., Rudovica, V., Viksna, A. (2011). Geographical dissemination of trace and major elements in honey. In: Brebbia, C. A. (ed.). Sustainability Today. WIT Press, Southampton, pp. 211-220, 488 ,

Vincevica-Gaile, Z. (2014). Impact of environmental conditions on microand macroelement content in selected food from Latvia. Disertācijas darbs [Vides apstākḷu ietekme uz mikro- un makroelementu saturu pārtikas produktos Latvijā. Doctoral thesis]. LU, Rīga, 179 lpp. (in English and in Latvian). Available at: http://www.lu.lv/fileadmin/user_upload/lu_portal/zinas/Zanes_Vincevicas-Gailes_prom_d_1.pdf (accessed 5 July 2015).

Received 31 July 2015

\section{MAKROELEMENTU UN MIKROLEMENTU DAUDZUMS DAŽĀDOS LATVIJĀ AUDZĒTOS GRAUDAUGOS}

Makroelementiem un mikroelementiem ir liela nozīme cilvēku ikdienas uzturā. Pasaulē 50\% pārtikas produktu ikdienas uzturā sastāda tieši graudaugi. Pētījuma mērkis bija noteikt makroelementu un mikroelementu daudzumu dažādos graudos, kas selekcionēti un audzēti Latvijā Valsts Stendes graudaugu selekcijas institūtā. Pētījumā tika izmantoti dažādi graudaugu veidi: rudzi $(n=45)$, mieži $(n=54)$, vasaras kvieši $(n=27)$, ziemas kvieši $(n=53)$, tritikāle $(n=45)$ un auzas $(n=42)$; kopā $n=266$. Graudos tika noteikti šādi makroelementi un mikroelementi (minerālvielas): $\mathrm{Cd}, \mathrm{Pb}, \mathrm{Ni}, \mathrm{Cr}, \mathrm{Al}, \mathrm{Cu}, \mathrm{K}, \mathrm{Na}, \mathrm{Mn}, \mathrm{Fe}, \mathrm{Zn}, \mathrm{Mg}, \mathrm{Cu}$. Minerālvielu saturs graudos bija būtiski atškirīgs $(p<$ $0,01$ vai $p<0,001)$. Dominējoši augstākais minerālvielu saturs tika konstatēts auzu un zemākais — rudzu graudos. Iegūtie pētījuma rezultāti paplašinās iespēju pārtikas un uztura zinātniekiem izvērtēt graudu pārstrādes produktos esošo un ar uzturu uzṇemto makroelementu un mikroelementu daudzumu un to biopieejamību organismam. 